\title{
Acknowledgments to the Sixth Edition
}

Before the first edition of this book was published, I imposed on several friends-all since deceased-and asked them to read it. Tadashi Aruga, Dorothy Borg, Michael Gasster, Stull Holt, and James C. Thomson Jr. responded with countless suggestions-which I valued even when I did not follow them. Robert A. Divine read it in his capacity as editor in the series in which it appeared, and Janice Prichard Cohen read it in an earlier incarnation as my wife. My readers saved me from considerable embarrassment and, if I were not so vain about my writing, they might have been able to help more.

Like every historian working in the field of American-East Asian relations, I was indebted to Dorothy Borg and John Fairbank for many of my ideas. In the years that followed, countless friends contributed further to my education and to the revisions and additions that appeared in subsequent editions. I am especially grateful to A. Doak Barnett, Richard Bush, Paul A. Cohen (who pretends to be my elder and wiser brother), Rosemary Foot, Harry Harding, Waldo Heinrichs, Michael H. Hunt, Akira Iriye, Walter LaFeber, James Mann, Ernest R. May, Michel Oksenberg, Nancy Bernkopf Tucker (long before she was foolish enough to marry me), and Allen S. Whiting for the many insights they provided through their work and the stimulating conferences and informal discussions in which we have participated over the years. 
I asked three friends-Tom Christensen, Bonnie Glaser, and Jim Mann-to read the section on Barack Obama. Although they acknowledged they were poor substitutes for Nancy, they were extremely helpful. In addition, Bonnie's regular essays on Chinese-American relations (currently three times a year) for Comparative Connections provide the most valuable chronology available.

I have also been fortunate over the years to have had assistance from many Chinese scholars-Li Shenzhi, Luo Rongqu, Wang Xi, and Zi Zhongyun - and others whom I dare not put at risk. Similarly, I had valuable conversations with many Chinese officials, of whom I assume Huang Hua and Xue Mouhong are safe from retribution.

Finally, I'd like to thank my editors at Columbia University Press for taking on America's Response to China after the demise of the original series. Kate Wittenberg arranged the transfer, Anne Routon continued her work, and Stephen Wesley has overseen this edition—all great people to work with. 